\title{
INCREASING LEARNING OUTCOMES USING COOPERATIVE LEARNING TYPE STUDENT TEAMS ACHIEVEMENT DIVISION (STAD) METHODOLOGY WITH FIFTH GRADE SECOND SEMESTER STUDENTS AT SD NEGERI SUMOGAWE 1 KEC. GETASAN, KAB. SEMARANG 2017/2018
}

\author{
Ika Yunita', Janelle Lee Juneau'2, Stefanus C. Relmasira ${ }^{3}$ \\ ${ }^{1}$ Pendidikan Guru Sekolah Dasar, Universitas Kristen Satya Wacana, ikayunita1207@gmail.com, \\ ${ }^{2}$ Pendidikan Guru Sekolah Dasar, Universitas Kristen Satya Wacana Janelle.juneau@staff.uksw.edu \\ ${ }^{3}$ Pendidikan Guru Sekolah Dasar, Universitas Kristen Satya Wacana stefanus.relmasira@staff.uksw.edu
}

INFO ARTIKEL
RiwayatArtikel:
Diterima: 23-03-2018
Disetujui: 06-04-2018

Keyword:

Cooperative learning Learning outcomes STAD

\begin{abstract}
ABSTRAK
Abstrak: Sesuatu yang dibutuhkan dalam matematika untuk kesuksesan hidup menghendaki lingkungan pembelajaran yang mendukung dan mendorong kompetensi matematika baik secara teori maupun praktik. Dalam pendidikan, mengajar matematika harus dengan cara yang kreatif dan mampu menciptakan suasana lingkungan dimana siswa tertarik untuk belajar matematika. Penelitian ini bertujuan untuk meningkatkan hasil belajar matematika melalui implementasi pembelajaran kooperatif dengan model pembelajaran STAD. Metode yang digunakan adalah Penelitian Tindakan Kelas (PTK) dengan 2 siklus, setiap siklus terdiri atas 3 pertemuan. Hasil dari siklus 1 ditemukan bahwa 28 siswa (82.35\%)mencapai batas ketuntasan (KKM) dengan rata-rata nilai 80. Pada siklus2, rata-rata nilai mencapai 87 dengan 34 siswa (100\%) mencapai batas ketuntasan. Berdasarkan hasil analisis dan diskusi dalam peneilitian ini, dapat disimpulkan bahwa impelentasi pembelajaran kooperatif dengan model pembelajaran STAD dapat meningkatkan hasil belajar matematika.
\end{abstract}

\begin{abstract}
The overwhelming need for mathematics comprehension for a successful life requires a learning environment that support and encourages both theoretical and practical math competency. In education, teaching mathematic should be creative and able to provide an environment where students are interested to learn mathematics. This study aimed to improve mathematic learning outcomes through the implementation of cooperative learning type STAD learning model. The method used in this research was a Classroom Action Research by conducting three meeting for each in two cycles. The result of the study in first cycle was found that 28 students (82.35\%) meet the school competency with average grade 80. In the second cycle, the average of learning achievement reached 87 with 34 students (100\%) meet the school competency. Based on the analysis and discussion of the research, it is concluded that the implementation of cooperative learning type STAD learning model can improve mathematic learning outcomes.
\end{abstract}

\section{A. BACKGROUND OF THE STUDY}

Mathematics knowledge is not just theoretical but also a practical need for daily life. Cockcroft (1986) stated that, "It would be very difficult - perhaps impossible - to live a normal life, in very many parts of the world, in the twentieth century, without making use of mathematics of some kind."Mathematics is used in all aspects of life from the simplest activity such as telling time to the intricate needs of a neurosurgeon. Mathematics is a tool to solve complex problems and a vital important part of daily life.Teaching mathematic is not about giving questions and the students answer the questions. In education, teaching mathematic should be creative and able to provide an environment where students are interested to learn mathematics.Current best-practice education methods use effective and creative learning environments so the students can learn easily and comfortably. Students will be able to be active in learning if they feel comfortable and happy. Effective teachers apply creative learning models appropriate to the curriculum, the learning, student's characteristics, and the lesson plan. Effective life-long learning is not just an individual activity but group learning is also necessary. Learning in groups is effective when students learn, help and encourage each other. "Cooperative learning is the instructional use of small groups in which students work together to maximize their own and each other's learning." (Johnson, D. W., \& Johnson, R. T., 1999). Cooperative learning is one learning model where student can learn in groups, help and encourage each other to reach maximum achievement. The researcher has seen that the mathematic learning in this school is classical, monotonous, teacher-directed, and not using the available media. The researcher did not observe the 
teacher using innovative or creative learning models. To make the learning more effective, the researcher applied a creative learning method.Based on that problem, the writer decides to use innovative learning. The innovative learning methods that the researcher used were cooperative learning. According to Laguador (2014), "Cooperative learning is an approach to the aim of student-cantered classroom activities towards the attainment of the outcomes-based environment as required by accrediting and certifying bodies and agencies of higher education." Slavin (2010) also states that, "Cooperative learning is an instructional method in which teachers organize students into small groups, which then work together to help one another learn academic content." Cooperative learning is defined as a process to help students interact together in order to accomplish a goal. The teacher completely controls the class even though the students work in groups. Cooperative learning is tools where the students learn in group, help and encourage each other to gain the understanding and gain the goals.

There are various types of cooperative learning; one of them is Student Teams Achievement Divisions (STAD). Student Teams Achievement Divisions (STAD) is a model in which students can learn in groups and help each other to accomplish the goals. According to Majoka, et al. (2010), "Student Team Achievement Division (STAD) is a cooperative-learning strategy in which small groups of learners with different levels of ability work together to accomplish a shared learning goal." In a STAD learning model, students are divided in groups heterogeneously. Students are grouped based on ability, gender, race and ethnicity. The teacher presents the lessons and students work in groups of 4-5 students each. The group has responsibility to make sure that all members understand the lesson and all problems and answers. Afterwards, all students do quizzes individually. Finally, the teacher combines the group points with the individual points for total points. The group with the highest total points will get a reward.

Mathematics knowledge is not just theoretical but also a practical need for daily life. According to Baglama, et al. (2017), "Mathematics is a tool for solving problems encountered in daily life." Cockcroft (1986) also stated that, "It would be very difficult - perhaps impossible to live a normal life, in very many parts of the world, in the twentieth century, without making use of mathematics of some kind." Mathematics is used in all aspects of life from the simplest activity such as telling time to the intricate needs of a neurosurgeon. Mathematics is a tool to solve complex problems and a vital important part of daily life.

Mathematics is knowledge used in daily life. According to Wahyudi (2012), "Mathematics is the universal language including ideas, knowledge and abstract concepts that cannot be separated from daily life." Mathematics is used in all aspects of life from the simplest activity such as telling time to the intricate needs of a neurosurgeon. There is not one school or educational institution without a mathematic curriculum. Mathematics is foundational for other subjects as well. According to Conroy, (Ling, 2016) "One of the goals in mathematic learning is to provide endless opportunities for students to expand and integrate mathematic knowledge, skills and practices."Through mathematics, students know how to unite theories, skills and practice. Mathematics knowledge is not just theoretical, but skills and practice is needed in daily life.

Mathematic is a tool that is used to solve the problem. According to Mawardi and Hanifah (2016), "The focus of mathematics is on how to solve problems." Polya's problem solving steps (Curcio, 1989), found four step method of problem solving namely: understand the problem, devise a plan, carry out the plan, look back and check.

A learning outcome is knowledge, skills and competency obtained after experiencing learning. Rusman (2012) states that, "A learning outcome is experience obtained, including the cognitive domain, affective domain, and psychomotor domain.” Learning outcomes are also abilities, attitudes and values obtained after experiencing learning. There are three domains of learning outcomes based on Blooms Taxonomy Theory (Abduljabbar, D. A., \& Omar, N. (2015); they are cognitive, affective and psychomotor domains.

The purposes of the research are increasing mathematic learning outcome using cooperative learning type Students Team Achievement Division (STAD) methodology with grade 5 second semester at SD Negeri Sumogawe 1 Kec. Getasan Kab. Semarang.

\section{B. RESEARCH METHOD}

The type of research used by the researcher is PTK (Classroom Action Research) a research design that consists of three stages of implementation (Kemmis and McTaggart, 1990). According to Arikunto (2010), "Classroom Action Research is research that is done in the class to improve or to increase the quality of the learning practice."This classroom action research utilizes a design consisting of four components: planning, action, observation and reflection and combines the components of action and observation as a whole (Kemmis and McTaggart, 1990). The result of the observations becomes the basis for reflection. From the reflection results, the researcher prepares modification for the planning in the next cycle and observes again and so forth. According to Kemmis and McTaggart (1990), this design of this research is a cyclical model.

In this research, the data were collected by using (1) Interview guidance to know the beginning condition, obstacle, and problem in mathematic learning. (2) Activity observation sheet to control the students and teacher activity. (3) Test to measure the mathematic learning outcomes. (4) Documentation. 
The researcher used data analysis technic by qualitative and quantitative descriptive. Qualitative descriptive describes what the problem is. Quantitative descriptive describe the learning outcomes in numeric. The subject of this research is fifth grade students at SDN Sumogawe 1. The total of the students is 34 .

\section{RESULT AND DISCUSSION}

\section{Initial Condition}

The mathematic learning is classical, monotonous, teacher-directed, and not using the available media. The researcher did not observe the teacher using innovative or creative learning models. The students were not enthusiastic, seemed bored, pretended to listen, were quiet, and become passive in learning.The students said that they learn using the teacher as the main resource, math drills, regardless of their understanding of the material and also the mathematics text books. The students didn't understand the material well and their grades were low. This is supported by mathematic learning outcome data for grade 5 . The students overall, got grade below or under the standard in the final test of the first semester; the school competency standard is 65. From the test outcomes, $50 \%$ of the students did not meet school competency standards, meaning 17 students passed and 17 did not. The lowest grade was 63.5 and the highest grade was 87.5.

\section{Cycle}

a. Learning outcomes of cycle 1

After three meetings of learning in cycle one, the students got the mathematic evaluation test. The results of the test are: maximum grade is 100, minimum grade is 60 , and the average is 80 . There are6 students (17.65\%) that didn't meet the school competency meaning 28 students $(82.35 \%)$ meet the school competency.

b. Learning outcomes of cycle 2

After three meetings of learning in second cycle, the students got the mathematic evaluation test. The results of the test are: maximum grade is 100 , minimum grade is 80 , and the average is 87 meaning 34 students (100\%) meet the school competency.

TABLE 1

Comparation The Learning Outcomes of Pre-Cycle, Cycle 1 and Cycle 2

\begin{tabular}{|c|c|c|c|c|}
\hline No & $\begin{array}{c}\text { Learning } \\
\text { Outcomes }\end{array}$ & $\begin{array}{c}\text { Pre- } \\
\text { Cycle }\end{array}$ & Cycle 1 & Cycle 2 \\
\hline 1 & $\begin{array}{l}\text { Maximum } \\
\text { grade }\end{array}$ & 87.5 & 100 & 100 \\
\hline 2 & $\begin{array}{l}\text { Minimum } \\
\text { grade }\end{array}$ & 63.5 & 60 & 80 \\
\hline 3 & Average & 66.72 & 80 & 87 \\
\hline 4 & $\begin{array}{l}\text { Completen } \\
\text { ess }\end{array}$ & $50 \%$ & $82.35 \%$ & $100 \%$ \\
\hline
\end{tabular}

From the table above describes the average on pre-cycle is 66.72 , on cycle 1 is 80 , and the second cycle is 87. Therefore, the implementation of cooperative learning type STAD increased mathematic learning outcomes.

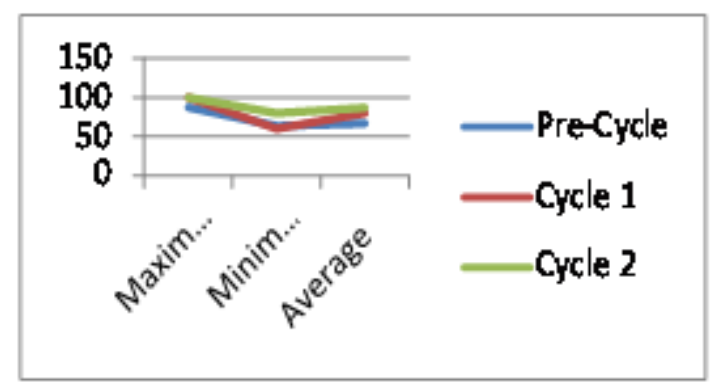

Picture1.Comparation of Learning Outcomes

\section{DISCUSSIONS}

Mathematic learning outcomes is measured by test. The average on pre-cycle showed 66.72 with 50\% completeness. After the learning used STAD learning model, the mathematic learning outcome was increased. The average of cycle 1 showed 80 with $82.35 \%$ completeness. From the reflection of cycle 1, the results did not meet the indicator of success yet. The researcher fixed the weakness of cycle 1 by grouping the students heterogeneous better and prepare the learning better than cycle 1 . The average of mathematic learning outcomes on second cycle is 87 with $100 \%$ completeness.

The implementation of STAD learning model gave positif effect to the class and the students. The effect of the students were the students become more active, brave to do presentation, encourage and help each other in learning also enjoy the learning. On the second cycle the learning is better as the mathematic learning outcomes was increase. It was in line with theory from Johnson (2014), "Cooperative learning is the instructional use of small groups so that students work together to maximize their own and each other's learning." Through cooperative learning, students work together to get maximum results.The advantages of STAD learning model are: (1) Encourages the students and teachers to be innovative and creative to improve teaching and learning of mathematics in the classroom (Ling, W. N. et al, 2016). (2) increasing skills of students for asking and discussion, give opportunity to help and encourage each other, students become more active, have positive interaction between students and teacher, and develop social skills (Slavin, 2005). (3) Encourages the students to be confident, interact positively, and be willing to give new ideas. STAD also encourages the teacher to motivate the student, willing to cooperate with others teacher, and how to manage the learning needs of all students.

\section{E. CONCLUSION AND SUGGESTION Conclusion}

According to the discussion above, it can be concluded that implementation of STAD learning model can increase mathematic learning outcomes of 
fifth grade second semester students at SD Negeri Sumogawe 1 Kec. Getasan, Kab. Semarang 2017/2018

\section{Suggestion}

Based on the research that already done, showed that the implementation of STAD learning model can increase the mathematic learning outcomes. Therefore, the writer suggest that(1) The teacher can develop the learning by implement the STAD learning model to make the student learn and motivate the student to learn mathematic. (2) The school can support the facilities for implementation of STAD learning model.

\section{ACKNOWLEDGEMENT}

The writer would like to thanks to Miss Janelle Lee Juneau, B.S.,El.Ed., M.Ed. as first consultant and Mr. Stefanus C. Relmasira, S.Pd., MS.Ed. as second consultant that always give guidance, advice, correction, revision and motivation until this research has done well.

\section{REFERENCES}

[1] Abduljabbar, D. A., \& Omar, N., "Exam Questions Classification Based on Bloom's Taxonomy Cognitive Level Using Classifiers Combination", Journal of Theoritical and Applied Information Technology, 78 (3), 4472015.

[2] Arikunto, S., Prosedur Penelitian: Suatu Pendekatan Praktik, Rineka Cipta, Jakarta 2010.

[3] Baglama, B., Yikmis, A., \&Demirok, M. S., "Special Education Teachers'view on Using Technology in Teaching Mathematics", European Journal of Special Education Research, 2017.

[4] Cockcroft, W.H, Mathematics Counts, HMSO, London, 1986.

[5] Johnson, D. W., \& Johnson, R. T., "Making Cooperative Learning Work", Theory into practice, 38(2), 67-73 1999.

[6] Johnson, D. W., \& Johnson, R. T., "Cooperative Learning in $21^{\text {st }}$ Century", Anales de Psicologia/Annals of Psychology, 30(3), 841-851 2014.

[7] Kemmis and McTaggart, The Action Research Planner, Deakin University, Victoria 3217, Australia 1990.

[8] Kusumawati, H., \& Mawardi, M., "Perbedaan Penerapan Model Pembelajaran Kooperatif Tipe NHT dan STAD Ditinjau dari Hasil Belajar Siswa”, Scholaria: Jurnal Pendidikan dan Kebudayaan, 6(3), 251-263 2016.

[9] Laguador, J. M., "Cooperative Learning Approach in an Outcomes-based Environment", International Journal of Social Sciences, Arts and Humanities, 2(2), 46-55 2014.

[10] Ling, W. N., Bin Ghazali, M. I., \& Raman, A., "The effectiveness of student teams-achievement division (STAD) cooperative learning on mathematics achievement among school students in Sarikei District, Sarawak", International Journal of Advanced Research and Development, 1(3), 17-21 2016.

[11] Majoka, M. I., Dad, M. H., \& Mahmood, T., "Student Team Achievement Division (SATD) as an Active Learning Strategy: Empirical Evidence from Mathematic Classroom", Journal of Education and Sociology, 4, 16-20 2010.
[12] Rusman., Model-Model Pembelajaran Mengembangkan Profesionalisme Guru, Rajawali Pers, Jakarta 2012.

[13] Slavin, Robert, E.,Cooperative Learning Teori, Riset dan Praktik, Nusa Media, Bandung, 2005.

[14] Slavin, Robert, E., Cooperative Learning Teori, Riset dan Praktik, Nusa Media, Jakarta, 2010.

[15] Wahyudi., Pemecahan Masalah Matematika, Widya Sari Press, Salatiga 2012.

\section{THE RESEARCHER PROFILE}

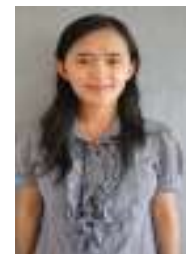

The writer is Ika Yunita. Was born on Magelang, 7 June 1995. The witer is the first children of two people. Elementary School was began from SDN Kenalan Kec. Pakis, Kab. Magelang on years 2002-2008. After that, was continued at SMPN 7 Salatigaof years 2008-2011 and then at SMKN 1 Salatiga of years 2011-2014. Then, the researcher was continued at Universitas Kristen SatyaWacana in Teacher Education Program of FKIP UKSW on 2014. Suggestion and criticism or the improvement of this research that has connection with my journal, you can be sent it via e-mail in: ikayunita1207@gmail.com 